Article

\title{
Synthesis of Hierarchical Zeolites with Morphology Control: Plain and Hollow Spherical Beads of Silicalite-1 Nanosheets
}

\author{
Kassem Moukahhal ${ }^{1,2,3}$, Bénédicte Lebeau ${ }^{1,2}{ }^{\circledR}$, Ludovic Josien ${ }^{1,2}$, Anne Galarneau ${ }^{4}$, \\ Joumana Toufaily $^{3}\left(\mathbb{D}\right.$, Tayssir Hamieh ${ }^{3}\left(\mathbb{D}\right.$ and T. Jean Daou ${ }^{1,2, *(\mathbb{D})}$ \\ 1 University of Haute Alsace (UHA), CNRS, Axe Matériaux à Porosité Contrôlée (MPC), Institut de Science \\ des Matériaux de Mulhouse (IS2M), UMR 7361, F-68093 Mulhouse, France; \\ kassem.moukahhal@uha.fr (K.M.); benedicte.lebeau@uha.fr (B.L.); ludovic.josien@uha.fr (L.L.) \\ 2 University of Strasbourg (UniStra), F-67000 Strasbourg, France \\ 3 Laboratory of Materials, Catalysis, Environment and Analytical Methods Faculty of Sciences, Section I, \\ Lebanese University Campus Rafic Hariri, Hadath, Lebanon; joumana.toufaily@ul.edu.lb (J.T.); \\ tayssir.hamieh@ul.edu.lb (T.H.) \\ 4 ICGM, University of Montpellier, CNRS, ENSCM, 34296 Montpellier, France; anne.galarneau@enscm.fr \\ * Correspondence: jean.daou@uha.fr; Tel.: +00-(33)-389336739
}

Academic Editor: Miguel A. Camblor

Received: 23 April 2020; Accepted: 26 May 2020; Published: 31 May 2020

\begin{abstract}
Binderless pure silica zeolites (zeosils) spheres and hollow spheres with a diameter of $20 \mu \mathrm{m}$ composed of silicalite- 1 nanosheets particles were prepared by pseudomorphic transformation of spherical silica beads using different temperatures $\left(110,130\right.$, and $\left.150{ }^{\circ} \mathrm{C}\right)$ and treatment times (1-5 days) in order to adapt the local dissolution rate of silica to the crystallization rate of silicalite- 1 nanosheets allowing to preserve the initial morphology of the silica beads. Fully crystalline beads of $20 \mu \mathrm{m}$ were obtained at $110^{\circ} \mathrm{C}$ for 5 days, whereas hollow spheres similar in size were synthesized at higher temperatures. The crystallization process seems to begin at the outer surface of the amorphous silica beads and spreads with the time in the interior of the beads leading to a dissolution of the inner amorphous part of the beads to create zeosil hollow spheres for the highest treatment temperatures $\left(130\right.$ and $\left.150^{\circ} \mathrm{C}\right)$. The dissolution rate of the inner amorphous part of the beads increases by increasing the hydrothermal treatment temperature from 130 to $150{ }^{\circ} \mathrm{C}$. The silicalite- 1 beads synthesized at $110^{\circ} \mathrm{C}$ for 5 days showed to be promising for rapid molecular decontamination by adsorbing $n$-hexane in larger amount than the silicalite- 1 conventional big crystals in powder forms.
\end{abstract}

Keywords: zeolites; zeosils; nanosheets; hierarchical zeolite; binderless zeolite; MFI; pollutant decontamination; volatile organic compounds; air purification

\section{Introduction}

Pure silica zeolites known under the name of zeosils are microporous materials with enhanced mechanical and thermal properties compared to aluminosilicate zeolites [1-5]. Due to their hydrophobic character, zeosils are excellent candidates for mechanical energy storage [3-5] and molecular decontamination [1,2,6-8]. In the case of molecular decontamination, these materials have the supplementary advantage on aluminosilicate zeolites that their volatile organic compounds (VOCs) sorption properties are not hindered by the significant quantity of water present in the air $[1,6]$.

However, conventional syntheses of zeolites give often rise to powders composed of micron-size crystals. Unfortunately, those powders cannot be used directly for industrial applications [9], especially for molecular decontamination because secondary dust contamination due to zeolite particles spreading could occurs [8,10-15]. The conventional micron-size crystals have also the disadvantages to induce 
some diffusional limitations. In order to overcome these constraints, shaping of hierarchical zeolite materials (beads, monoliths, etc.) composed of nanocrystals is needed. This synthesis strategy has the advantage to give a usable product for molecular decontamination, which avoids diffusional problems and possesses higher porous volume (due to the introduction of additional porosity) and therefore adsorption properties than conventional zeolites.

Zeolite microspheres with hierarchical porosities are emerging as attractive materials for applications in adsorption and catalysis [11,12,16-18]. Hollow zeolite spheres have been fabricated by assembly of nano-zeolites into macroscopic structures and removal of templates [19-22].

Zeolite microspheres composed of small crystals were prepared by using templates, which, upon removal, determine the pore structure of the products. Wang et al. [23] developed a new method for the preparation of silicalite- 1 microspheres using impregnated monodispersed micron-sized poly-styrene-co-divinylbenzene porous particles as template. Yin et al. [24] used dimethyldiallyl ammonium chloride acrylamide copolymer as a template for fast and one-step formation of nano-zeolite beta microspheres. Tao et al. [25] reported space-confined synthesis route of hierarchical MFI zeolite microspheres respectively with nanorod oriented-assembled structures of a carbon-silica composite monolith via hydrothermal treatment. Wang et al. [26] hydrothermally synthesized hierarchical ZSM-5 zeolite microspheres by using organo-functionalized silanized mesoporous silica as silica source. The preparation of spherical macrostructures employing anion exchange resin beads as templates was also reported by Tosheva et al. [27,28], Yin et al. [29], and our team [16] for MFI, *BEA and LTA-type zeolites. Zeolite beads with tuned size were also elaborated in two steps thanks to a shearer/mixer in the presence of carboxymethylcellulose, sodium metasilicate, or clays as binders [11,12].

The above reported methods have the disadvantage of using a shape directing templates or binders. Therefore, simple and binderless methods to synthesize hierarchical shaped zeolite are required such as pseudomorphic transformation [3-30].

By exploiting the concept of pseudomorphic transformation, i.e., using silica amorphous beads or monoliths featuring mesopores as silica source, the group of A. Galarneau was able to shape SOD, LTA, FAU (13X) zeolites, featuring an Si/Al ratio close to 1, as beads of $10 \mu \mathrm{m}, 60 \mu \mathrm{m}$, and $1 \mathrm{~mm}$ [18] and as monoliths of $0.6 \mathrm{~cm}$ diameter and $3 \mathrm{~cm}$ length with hierarchical porosity (micro-/meso-/macroporosity) [31,32] without binders. The zeolite beads have the same size and shape as the initial amorphous silica beads used in the pseudomorphic synthesis. Recently, we succeeded to obtain hierarchical MFI zeolite beads as ZSM- 5 with $\mathrm{Si} / \mathrm{Al}$ ratio around 40 by the pseudomorphic synthesis technology [33]. Different diameters of beads were obtained (20,50, and $75 \mu \mathrm{m})$ and each bead was built by the assembly of ZSM- 5 zeolite nanosheets of $2 \mathrm{~nm}$ thickness. To our knowledge, no studies involving pseudomorphic transformation, has been reported for the direct synthesis of pure silica MFI zeolite beads composed of small silicalite-1 nanocrystals with hierarchical porosity involving inter-crystalline mesopores.

Silicalite-1 zeosil belong to MFI-structure type, which is characterized by a porous network formed by the interconnection of straight circular channels $(5.4 \AA \times 5.6 \AA)$ with sinusoidal and elliptical channels $(5.1 \AA \times 5.4 \AA)[1-5,34]$. The latter structure is of particular interest for several environmental applications such as energy storage [3-5] and air purification as VOCs adsorption [1,2,6].

This work will therefore address the synthesis of hierarchical silicalite- 1 zeolite beads and hollow spheres composed of zeosil nanosheets using amorphous silica beads of $20 \mu \mathrm{m}$ in size as starting material for the pseudomorphic transformation. The effect of hydrothermal treatment time and temperature on the pseudomorphic synthesis of pure and well-crystallized silicalite- 1 beads and hollow spheres and their ability to adsorb n-hexane, a well-known VOC, will be discussed.

\section{Results and Discussion}

The crystallinity and purity of the synthesized silicalite- 1 beads obtained by pseudomorphic transformation of silica beads using typical diquaternary ammonium surfactant C22-6-6 to produce MFI nanosheets were first checked by X-ray diffraction (XRD). According to the XRD patterns reported 
in Figure 1, the materials obtained after 2 or 3 days of synthesis at $110^{\circ} \mathrm{C}(\mathrm{B} 110-2$ and B110-3) contains MFI-type zeolite (silicalite-1) with some amorphous materials. In order to avoid the presence of amorphous phase, the syntheses were then conducted at higher crystallization time (5 days) or higher temperatures, 130 and $150{ }^{\circ} \mathrm{C}$. When the synthesis time at $110^{\circ} \mathrm{C}$ was increased to 5 days or the synthesis temperature was increased to 130 and $150{ }^{\circ} \mathrm{C}$, pure silicalite- 1 zeolite samples were obtained. For all these samples, the XRD diffraction peaks are less intense than those of the conventional nanosheet silicalite-1 featuring crystal size of several micron [2,3]. Using amorphous silica beads as silica source for the synthesis of silicalite- 1 zeolite beads composed of nanosheets seems to accelerate the kinetic of crystallization compared to the conventional synthesis of silicalite- 1 nanosheets powder using tetraethylorthosilicate (TEOS) as silica source (as mentioned in our previous paper) [2]. With TEOS 10 days of crystallization at $110^{\circ} \mathrm{C}$ were needed to obtain fully crystallized MFI-type nanosheets exempt of amorphous phase, whereas only 5 days were enough with silica beads for the same synthesis temperature. Moreover, all the diffraction peaks observed on the XRD patterns of the samples synthesized at 110 and $130{ }^{\circ} \mathrm{C}$ belong to the crystallographic plane (h01), providing the sign that a one-dimension growth-inhibition is undertaken along the $b$-axis ( $2 \mathrm{~nm}$ of thickness), thus leading to the formation of nanosheets $[2,3,35,36]$. When the synthesis temperature was increased up to $150{ }^{\circ} \mathrm{C}$ additional (hkl) (with $\mathrm{k} \neq 0$ ) peaks with low intensities corresponding also to MFI-type zeolite structure are detected indicating the presence of bigger crystallites or higher thickness of the sheets.

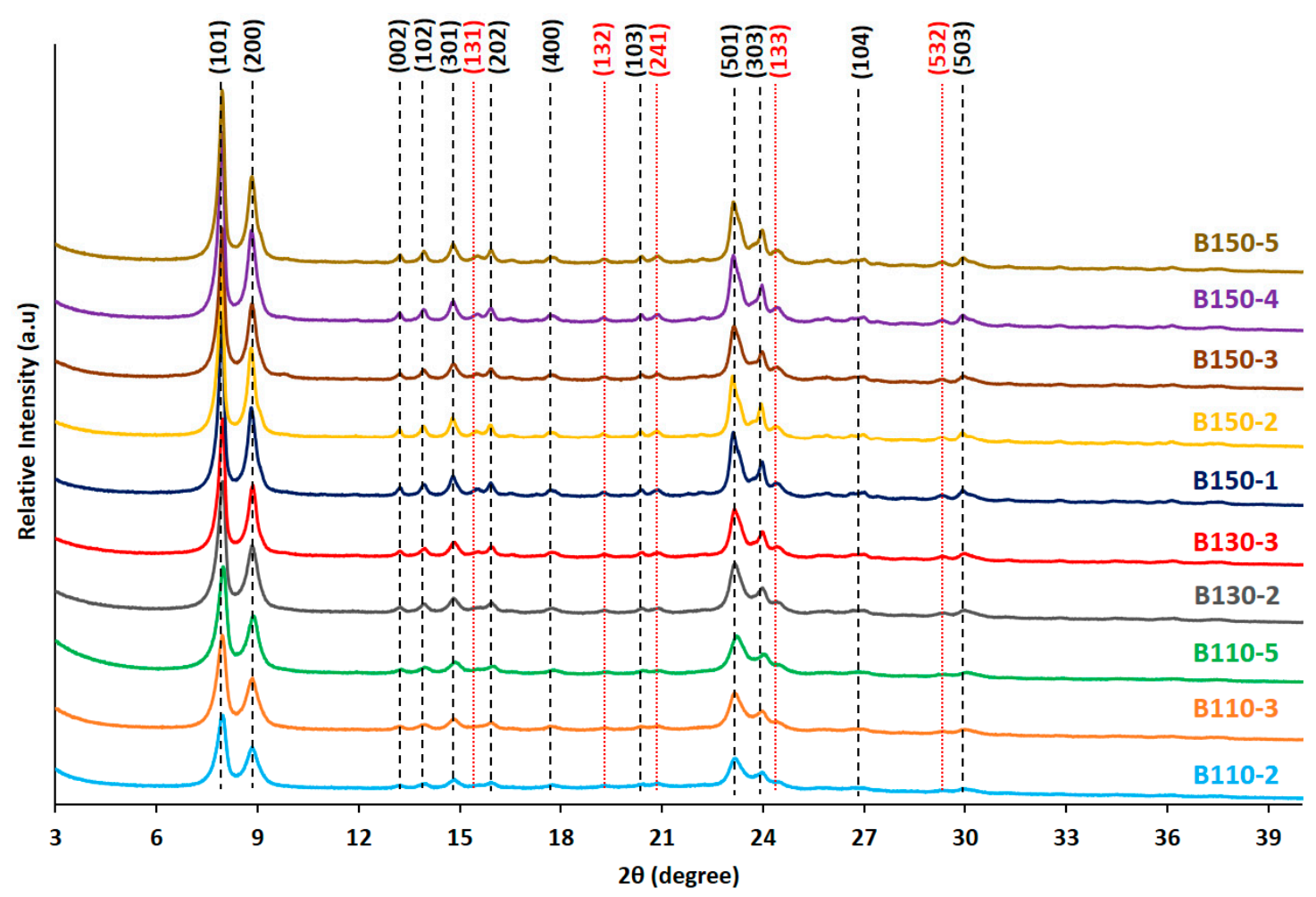

Figure 1. X-ray diffraction (XRD) patterns of calcined silicalite- 1 beads $\left(\mathrm{B}-\mathrm{T}\left({ }^{\circ} \mathrm{C}\right)-\mathrm{t}(\right.$ days $\left.)\right)$ obtained at different temperatures and treatment times.

Scanning electron microscopy (SEM) images displayed in Figure 2 show the conservation of the initial spherical morphology and size $(20 \mu \mathrm{m})$ of the amorphous silica beads. The silicalite- 1 beads are composed of an agglomeration of zeolite particles of 0.2-2.8 $\mu \mathrm{m}$ diameter (Table 1), each composed of silicalite-1 nanosheets. The size of the silicalite-1 particles (resulting from nanosheets agglomeration) seems to increase by increasing the hydrothermal treatment time and temperature (Table 1). 

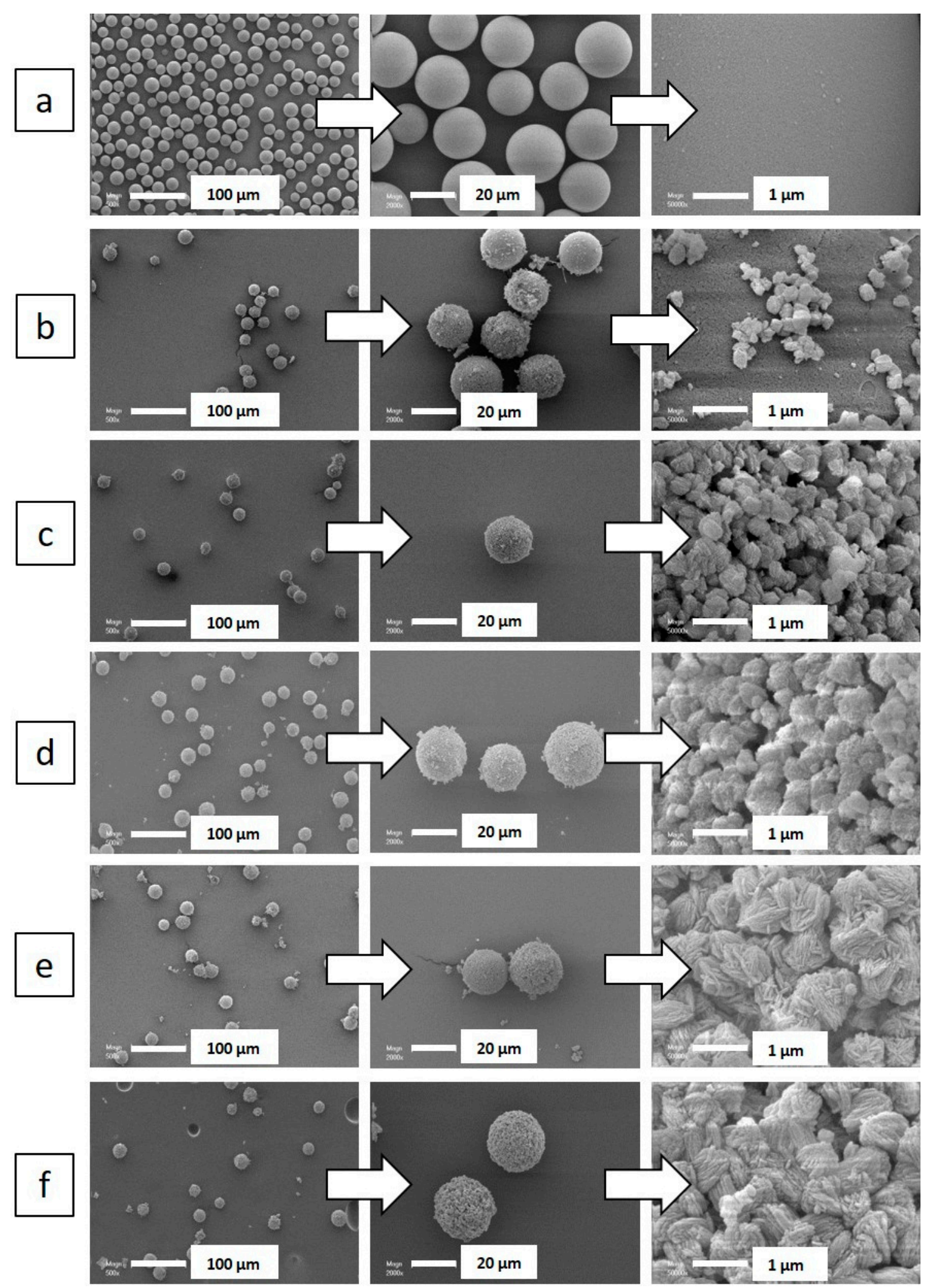

Figure 2. Cont. 

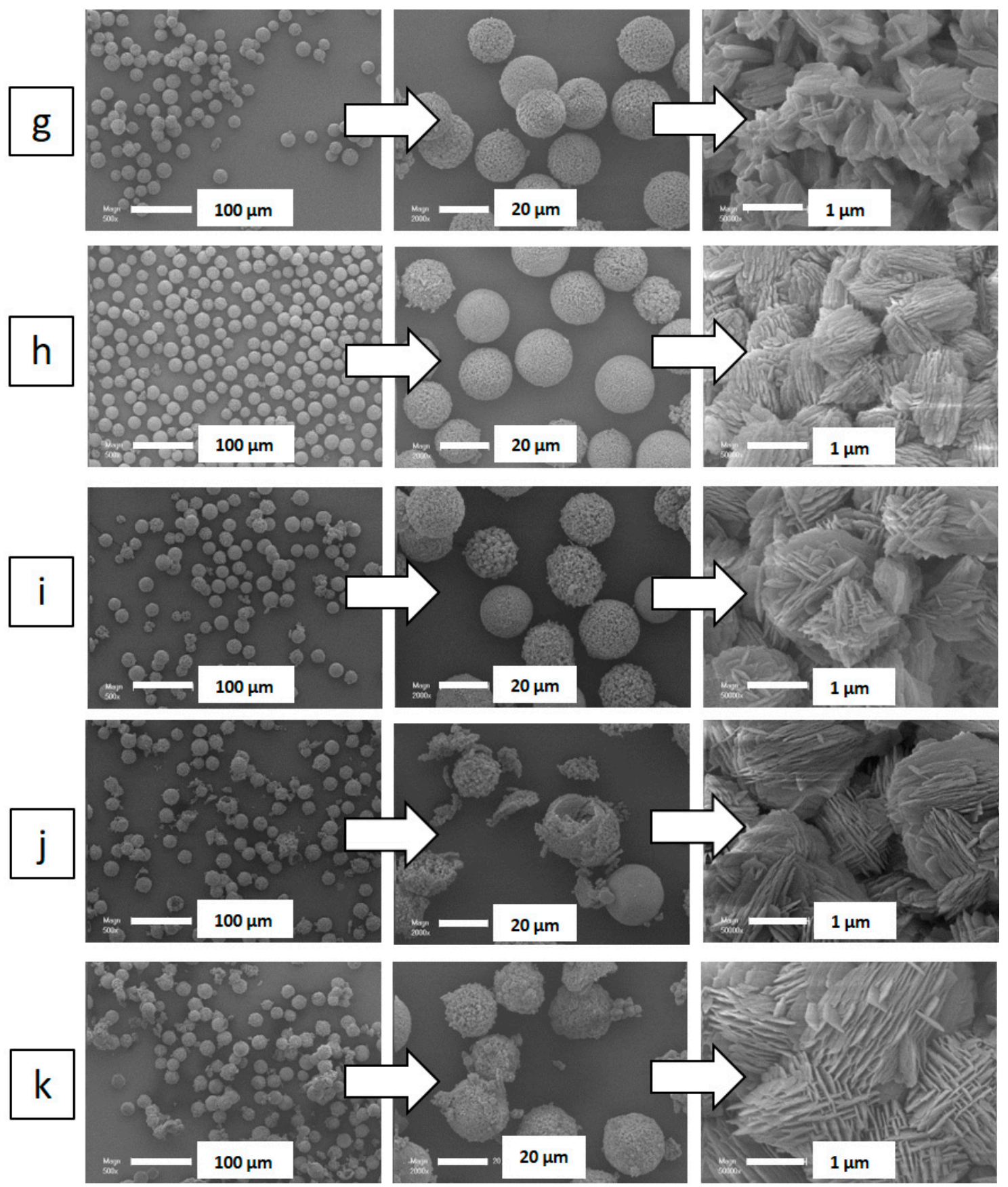

Figure 2. Scanning electron microscopy (SEM) images of: (a) amorphous $20 \mu \mathrm{m}$ silica spheres, and silicalite- 1 beads as a function of their temperature and duration synthesis $\left(\mathrm{B}-\mathrm{T}\left({ }^{\circ} \mathrm{C}\right)-\mathrm{t}(\right.$ days $\left.)\right)$ : $(\mathbf{b}) \mathrm{B} 110-2$, (c) B110-3, (d) B110-5, (e) B130-2, (f) B130-3, (g) B150-1, (h) B150-2, (i) B150-3, (j) B150-4, and (k) B150-5. 
Table 1. Diameter of the particles and thickness of the nanosheets building the $20 \mu \mathrm{m}$ silicalite- 1 beads obtained by pseudomorphic transformation. Silicalite- 1 beads are presented as a function of their temperature and duration of synthesis $\left(\mathrm{B}-\mathrm{T}\left({ }^{\circ} \mathrm{C}\right)-\mathrm{t}(\right.$ days $\left.)\right)$.

\begin{tabular}{ccc}
\hline & $\begin{array}{c}\text { Particle Diameter } \\
(\mu \mathrm{m})\end{array}$ & $\begin{array}{c}\text { Nanosheet Thickness } \\
(\mathbf{n m})\end{array}$ \\
\hline B110-2 & 0.2 & 2 \\
\hline B110-3 & 0.3 & 2 \\
\hline B110-5 & 0.5 & 2 \\
\hline B130-2 & 0.6 & 2 \\
\hline B130-3 & 1.2 & 2 \\
\hline B150-1 & 0.8 & 4 \\
\hline B150-2 & 1.4 & 5 \\
\hline B150-3 & 1.8 & 7 \\
\hline B150-4 & 2.0 & 7 \\
\hline B150-5 & 2.8 & 10 \\
\hline a Particles obtained by nanoshets assembly/agglomeration
\end{tabular}

${ }^{a}$ Particles obtained by nanosheets assembly/agglomeration.

Transmission electron microscopy (TEM) images given in Figure 3 show that the silicalite-1 nanosheets composing the beads obtained after a hydrothermal treatment temperature of 110 and $130{ }^{\circ} \mathrm{C}$ have a thickness of $2 \mathrm{~nm}$. An increase of the nanosheet size $(4-8 \mathrm{~nm})$ composing the beads is observed for hydrothermal treatment at $150{ }^{\circ} \mathrm{C}$ (Table 1). Increasing the duration of the hydrothermal treatment at $150{ }^{\circ} \mathrm{C}$ seems also to increase also the nanosheet thickness from 4 to $8 \mathrm{~nm}$ (Table 1). This is consistent with XRD data, where additional (hkl) (with $\mathrm{k} \neq 0$ ) peaks with low intensities are observed for these samples. This phenomenon could be explained by "Ostwald ripening" which is usually observed in inorganic synthesis where small crystals dissolve to generate the growth of big crystals and/or the dissolution of inner amorphous silica of the beads because pseudomorphic transformation is known to begin at the outer surface of the samples and diffuse with time to the inner part of the samples [33]. In order to see the evolution of the interior part of the beads as function of the treatment temperature and time, SEM images (Figure 4) of the synthesized samples embedded in polymer and then grinded were realized. The crystallization seems to begin at the outer surface of the beads. While further increasing the hydrothermal temperature $\left(130\right.$ and $\left.150{ }^{\circ} \mathrm{C}\right)$, the dissolution kinetic of the inner amorphous part of the beads seems to increase allowing the formation of a majority of hollow spheres instead of a majority of fully crystallized beads obtained at $110{ }^{\circ} \mathrm{C}$ for 5 days of treatment (sample B110-5).

The textural properties of the synthetized silicalite- 1 beads were studied by $\mathrm{N}_{2}$ sorption isotherm at $-196{ }^{\circ} \mathrm{C}$. Figure 5 shows the isotherms of the different calcined silicalite- 1 beads obtained by pseudomorphic transformation in comparison to the parent amorphous silica beads. T-plot analysis [37] have been performed (Figure S1) and their textural properties are summarized in Table 2. The underestimation of microporous volumes and the overestimation of surface areas determined from the classical t-plot analysis have been corrected by using the abacus proposed by Galarneau et al. [37] for hierarchical zeolites featuring microporous volume to the total pore volume ratio $\left(\mathrm{V}_{\text {micro }}\right.$ $\left.(t-p l o t) / \mathrm{V}_{\text {tot }(t-p l o t)} \%\right)$ higher than $20 \%$. 

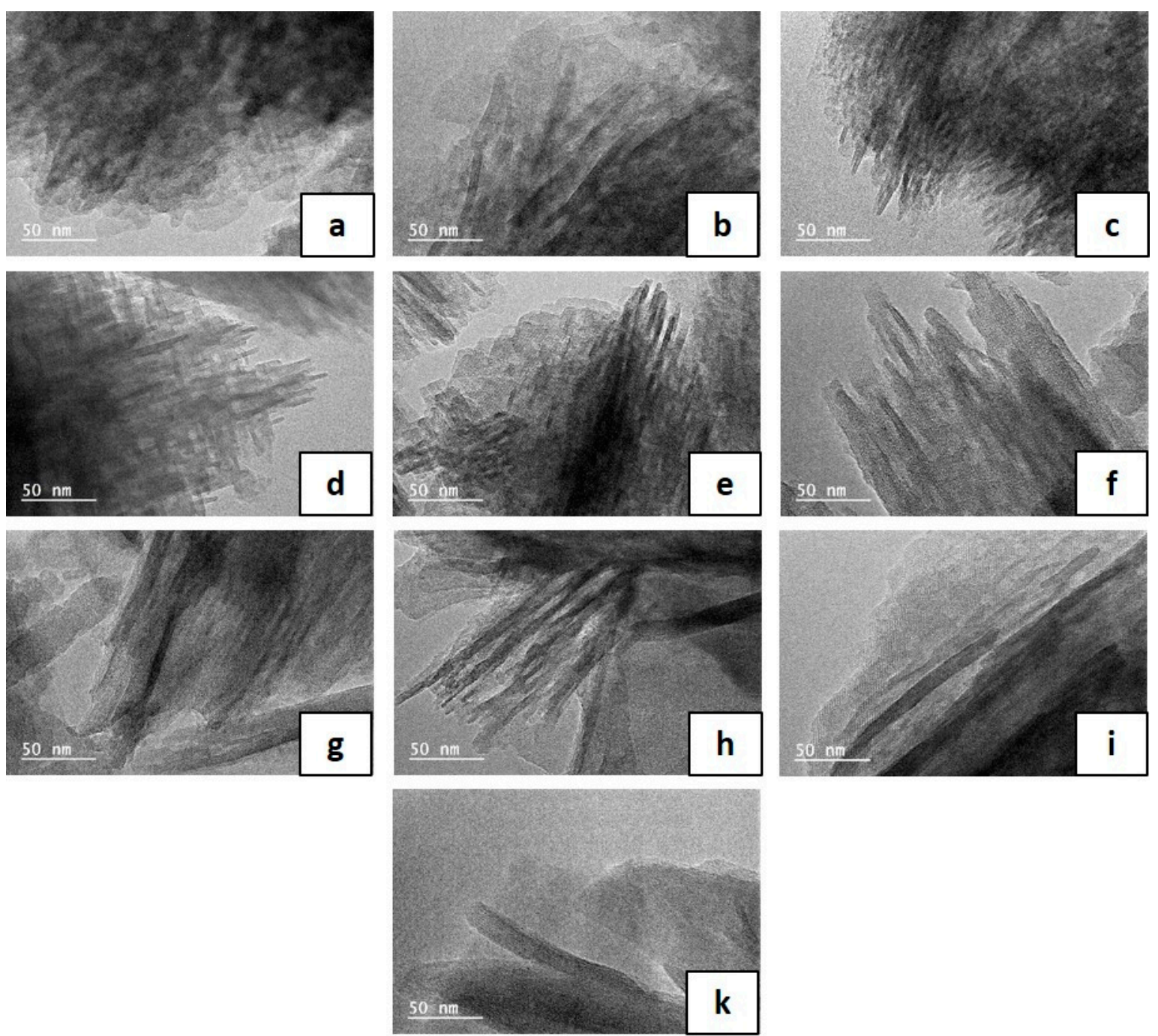

Figure 3. Transmission electron microscopy (TEM) images of silicalite-1 beads as a function of their temperature and duration synthesis $\left(\mathrm{B}-\mathrm{T}\left({ }^{\circ} \mathrm{C}\right)-\mathrm{t}(\right.$ days $\left.)\right)$ : (a) B110-2, (b) B110-3, (c) B110-5, (d) B130-2, (e) B130-3, (f) B150-1, (g) B150-2, (h) B150-3, (i) B150-4, and (j) B150-5. 

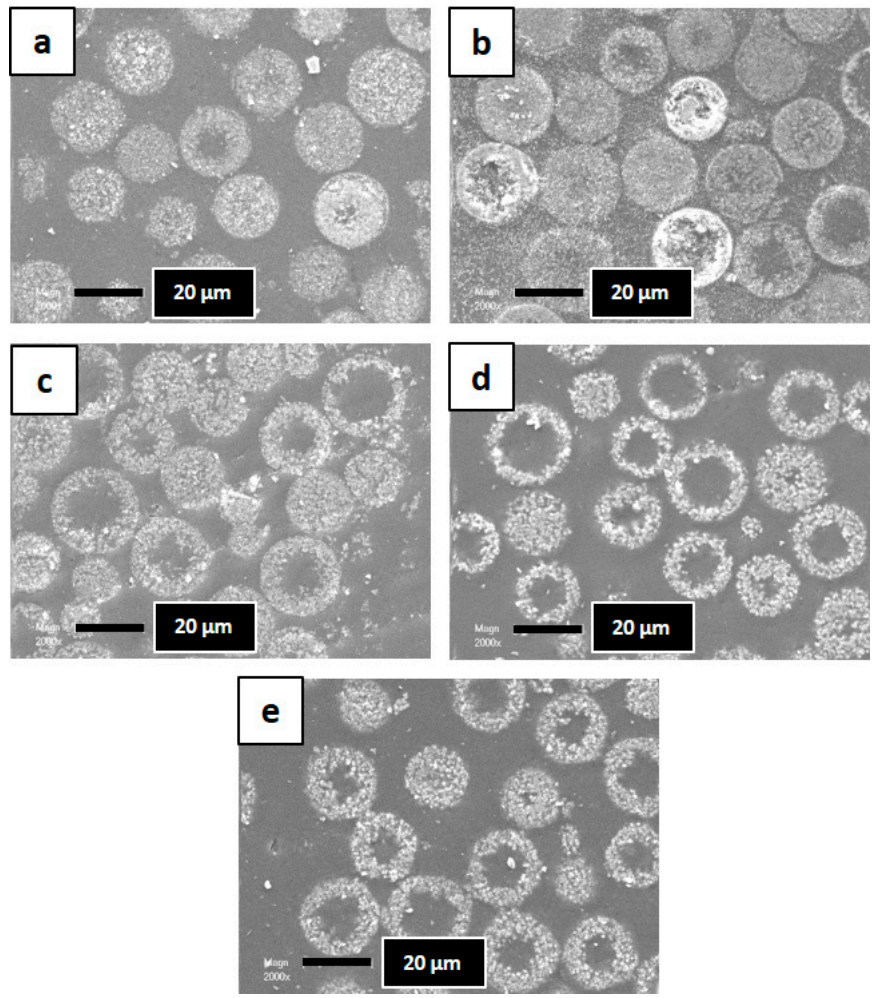

Figure 4. SEM images of the synthesized silicalite-1 beads embedded in polymer and grinded. Silicalite-1 beads are presented as a function of their temperature and duration synthesis $\left(\mathrm{B}-\mathrm{T}\left({ }^{\circ} \mathrm{C}\right)-\mathrm{t}(\right.$ days $\left.)\right)$ : (a) B110-3, (b) B110-5, (c) B130-2, (d) B150-1, and (e) B150-5.

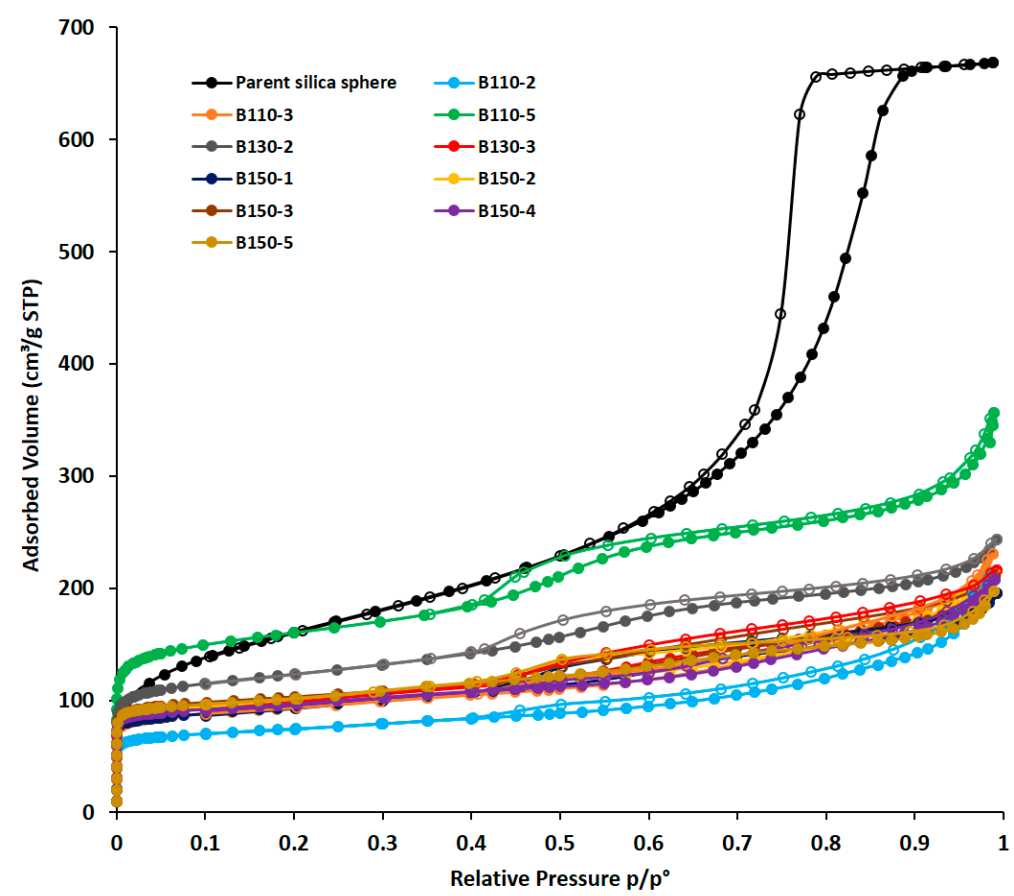

Figure 5. $\mathrm{N}_{2}$ adsorption-desorption isotherms at $-196{ }^{\circ} \mathrm{C}$ of the calcined silicalite- 1 beads obtained by pseudomorphic transformation at different temperatures (T) and durations (time) (B-T $\left({ }^{\circ} \mathrm{C}\right)$-time (days)) compared to the parent silica bead. 
Table 2. Textural properties of the calcined materials synthetized by pseudomorphic transformation and of the parent amorphous silica spheres. Silicalite- 1 beads are presented as a function of their temperature and duration synthesis $\left(\mathrm{B}-\mathrm{T}\left({ }^{\circ} \mathrm{C}\right)-\mathrm{t}(\right.$ days $)$.

\begin{tabular}{|c|c|c|c|c|c|c|c|c|c|}
\hline & $\begin{array}{l}S_{\text {BET }}{ }^{a} \\
\left(\mathrm{~m}^{2} / g\right)\end{array}$ & $\begin{array}{l}S_{\text {mic }} b \\
\left(\mathrm{~m}^{2} / g\right)\end{array}$ & $\begin{array}{l}S_{\text {mes }} b \\
\left(m^{2} / g\right)\end{array}$ & $\begin{array}{c}S_{\text {ext }} \\
\left(\mathrm{m}^{2} / \mathrm{g}\right)\end{array}$ & $\begin{array}{l}V_{\text {tot }}{ }^{c} \\
\left(\mathrm{~cm}^{3} / \mathrm{g}\right)\end{array}$ & $\begin{array}{l}V_{\text {micro }} b \\
\left(\mathrm{~cm}^{3} / \mathrm{g}\right)\end{array}$ & $\begin{array}{l}V_{\text {meso }} b \\
\left(\mathrm{~cm}^{3} / \mathrm{g}\right)\end{array}$ & $\begin{array}{l}\text { Mesopore } \\
\text { Diameter } \\
{ }^{d}(\mathrm{~nm})\end{array}$ & $\begin{array}{l}\text { Crystallization } \\
\text { Degree (\%) }\end{array}$ \\
\hline $\begin{array}{l}\text { Parent } \\
\text { silica } \\
\text { sphere }\end{array}$ & 545 & & & & 1.04 & & & $3.4-6.4-10.7$ & 0 \\
\hline B110-2 & 282 & 191 & 0 & 91 & 0.329 & 0.106 & 0 & $3.3-6.6-9.1$ & 58 \\
\hline B110-3 & 354 & 246 & 0 & 108 & 0.357 & 0.137 & 0 & $2.3-3.3-8.6$ & 76 \\
\hline B110-5 & 595 & 398 & 45 & 152 & 0.552 & 0.189 & 0.184 & 4.3 & 100 \\
\hline B130-2 & 458 & 327 & 31 & 100 & 0.377 & 0.155 & 0.135 & 4.7 & 86 \\
\hline B130-3 & 374 & 246 & 0 & 128 & 0.335 & 0.134 & 0.105 & 5 & 74 \\
\hline B150-1 & 352 & 251 & 0 & 101 & 0.302 & 0.138 & 0.087 & $3.4-5.4$ & 76 \\
\hline B150-2 & 381 & 296 & 0 & 85 & 0.330 & 0.162 & 0.014 & $3.2-6.4$ & 90 \\
\hline B150-3 & 395 & 284 & 0 & 111 & 0.326 & 0.157 & 0.078 & $3.4-5.5$ & 87 \\
\hline B150-4 & 370 & 283 & 0 & 87 & 0.321 & 0.155 & 0.080 & $3.4-5.5$ & 86 \\
\hline B150-5 & 390 & 296 & 0 & 94 & 0.305 & 0.162 & 0.063 & $3.4-5.5$ & 90 \\
\hline
\end{tabular}

a Specific surface area determined by using BET (Brunauer-Emmet-Teller) method. ${ }^{\mathrm{b}}$ Determined from t-plots with corrections if needed according to Galarneau et al., Langmuir, 2014, 2018. ${ }^{\mathrm{c}}$ Total pore volume determined at the relative pressures $\mathrm{p} / \mathrm{p}^{\circ}=0.99$. ${ }^{\mathrm{d}}$ Determined from the pore size distribution obtained by DFT method applied on the adsorption branch of isotherm. ${ }^{\text {e }}$ Crystallization degree $=V_{\text {micro zeolitic }} / V_{\text {micro zeolitic of reference MFI nanosheets; }}$; $\mathrm{V}_{\text {micro zeolitic of reference silicalite- } 1}=0.18 \mathrm{~cm}^{3} / \mathrm{g}$.

All of the isotherms are type I according to IUPAC [38] at low relative pressures and type II-b with hysteresis at high relative pressures. The presence of a hysteresis in the relative pressure range $0.4<\mathrm{p} / \mathrm{p}^{\circ}<1$ is typical of lamellar materials, due to the stacking of the nanosheets. The comparison with the isotherm of the parent $20 \mu \mathrm{m}$ amorphous silica bead shows that the capillary condensation steps occur at a different relative pressure indicating that these small mesopores are formed during the crystallization of silicalite-1 nanosheets. However, since the distribution of mesopore size for parent $20 \mu \mathrm{m}$ beads is wide and overlapping those of transformed beads it is not excluded that residual mesoporosity from parent beads remains as observed from the mesopores diameters determined from DFT (Density Functional Theory) for samples B110-2 and B110-3. From DFT pore size distributions of transformed beads and hollow spheres shown in Figure 6, micropores characteristics of MFI zeolite with sizes of 0.51 and $0.56 \mathrm{~nm}$ are observed. The crystallization degrees of silicalite- 1 nanosheets beads and hollow spheres obtained by pseudomorphic transformation were thus estimated by comparing the microporous volumes corresponding to zeolitic micropores with the one of well crystallized MFI-type zeolite $(0.18 \mathrm{~mL} / \mathrm{g})$. For the silicalite- 1 beads synthesized at $110^{\circ} \mathrm{C}$, an increase in the zeolitic microporous volume and the degree of crystallization is observed while increasing the hydrothermal treatment time from 2 to 5 days. The low crystallization degree of samples B110-2 and B110-3 is in agreement with the presence of an amorphous phase observed by XRD. When comparing the samples obtained after 2 days of hydrothermal treatment but at different temperatures, the crystallization degree seems to increase by increasing the hydrothermal treatment temperature from 110 to $150{ }^{\circ} \mathrm{C}: 58 \%$ for sample B110-2, 86\% for sample B130-2, and 90\% for sample B150-2. The same trend is observed for the samples synthesized after 3 days of hydrothermal treatment but the increase of the crystallization degree imposed by the increase of the treatment temperature is less significant at 3 days compared to 2 days. When the hydrothermal time was increased to 5 days, the trend is inversed and the best crystallization degree (100\%) is found for sample B110- 5 obtained after 5 days at $110^{\circ} \mathrm{C}$. This result could be explained by the fact that at higher treatment temperature and longer treatment time the dissolution of amorphous silica and "Ostwald ripening" are higher. The sample with the highest micropore volume, the highest mesopore volume and the highest surface areas (micro, meso-, and external) is the silicalite- 1 beads obtained at $110^{\circ} \mathrm{C}$ for 5 days (B110-5) (Table 2). However, the obtained hollow spheres (samples obtained at 130 and $150^{\circ} \mathrm{C}$ ) are also promising materials for rapid processes 
under high flow rate and the sample obtained at $130{ }^{\circ} \mathrm{C}$ for 2 days (B130-2) appears to have the highest mesopore volume for similar micropore volumes and the highest micropore surface area and mesoporous and external surface area. These two silicalite-1 samples are good candidates to be tested in adsorption flow processes of air pollutants.

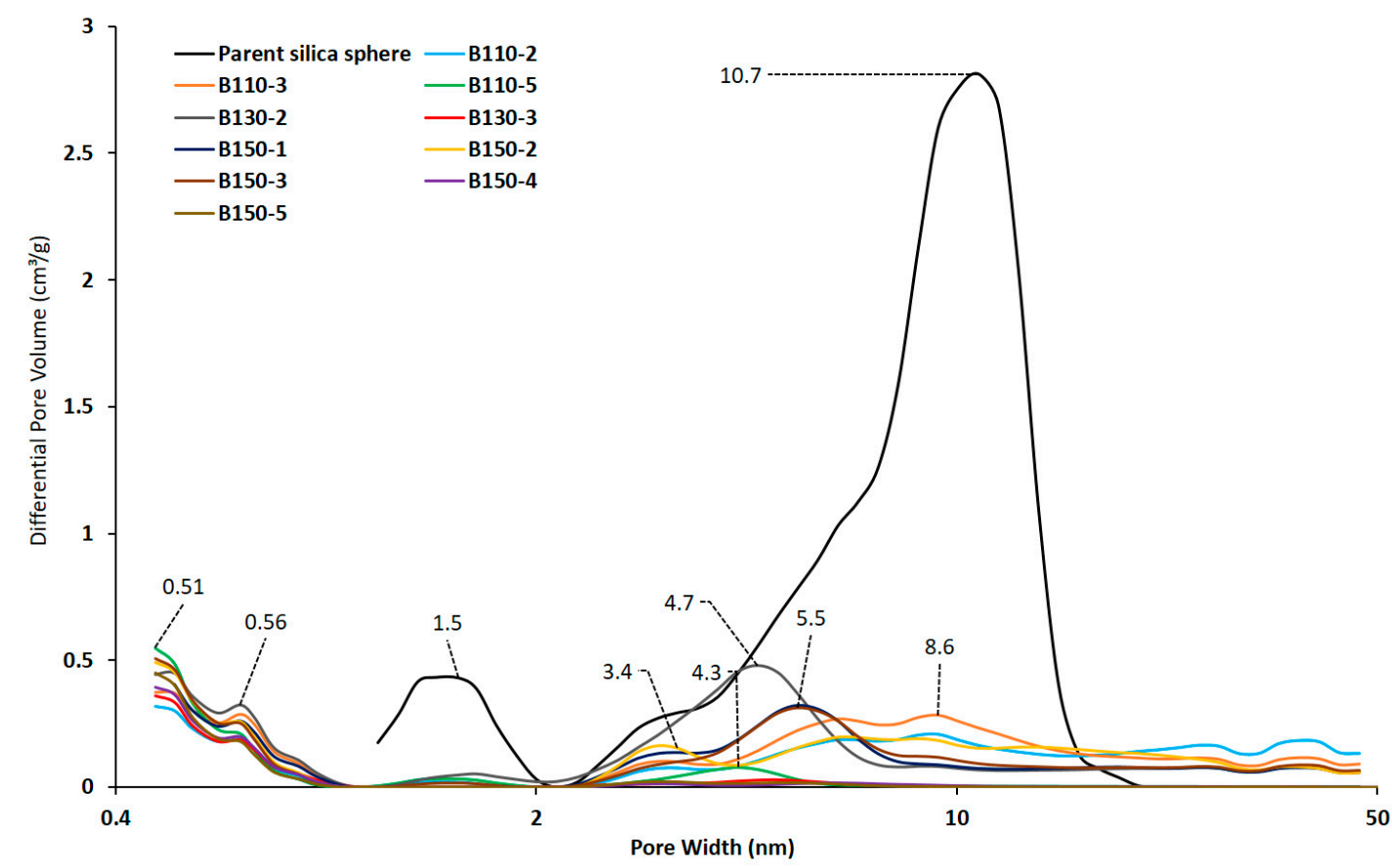

Figure 6. DFT (Density Functional Theory) pore size distributions determined from the adsorption branch of the $\mathrm{N}_{2}$ isotherms of calcined silicalite- 1 beads obtained by pseudomorphic transformation at different temperatures $(\mathrm{T})$ and durations (time in days) $\left(\mathrm{B}-\mathrm{T}\left({ }^{\circ} \mathrm{C}\right)-\mathrm{t}(\right.$ days $\left.)\right)$ compared to the parent silica bead.

According to the results of textural and structural characterization shown above, a mechanism is proposed in Figure 7. Independently from the temperature and the treatment time, the crystallization seems to begin at the outer surface of the beads. While further increasing the hydrothermal temperature, the dissolution kinetic of the inner amorphous part of the beads seems to increase allowing the formation of a majority of hollow spheres instead of a majority of fully crystallized beads obtained at $110{ }^{\circ} \mathrm{C}$ for 5 days of treatment. Taking into account this information, and knowing from the TEM images that the length of silicalite- 1 nanosheets is about $2 \mathrm{~nm}$ for the sample synthesized at 110 and $130{ }^{\circ} \mathrm{C}$, and that this thickness seems to increase at $150{ }^{\circ} \mathrm{C}$ up to $8 \mathrm{~nm}$ a mechanism is proposed in Figure 7 .

The $n$-hexane sorption capacity of the calcined conventional silicalite- 1 zeosil at $25^{\circ} \mathrm{C}$ is expected to be around 111-120 mg/g which corresponds to 7.4-8 molecules of $n$-hexane per MFI unit cell [1,2,6,39]. B110-5 and B150-3 showed a sorption capacity around 197 and $115 \mathrm{mg} / \mathrm{g}$, respectively (which corresponds to 13.4 and 7.7 molecules of n-hexane per MFI unit cell). B110-5 sample is a highly promising material because it possesses higher adsorption capacities compared to conventional silicalite- 1 microcrystals. The enhanced uptake rate of the $\mathrm{n}$-hexane in B110-5 sample must be attributed to an improved accessibility, to a shorter diffusion path length in the micropores and to the presence of additional mesoporous volume. No loss of n-hexane adsorption capacity is observed for B110-5 compared to what is usually obtained for silicalite-1 nanosheets in powder form [2]. The adsorption curves in Figure 8 were reproduced three times over each sample. Hollow spheres as (B150-3) show highest initial rate of adsorption and might be promising for processes with higher flow rate. All hollow spheres should be tested. 


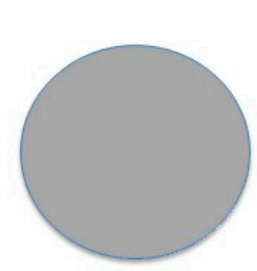

Amorphous silica

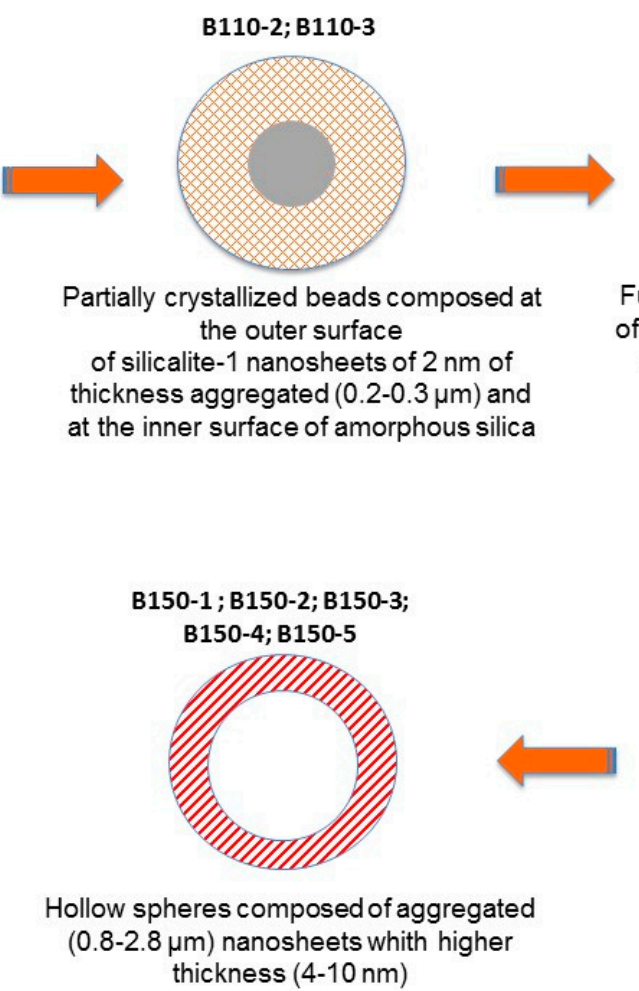

B110-5

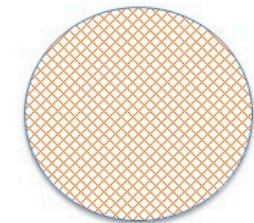

Fully crystallized beads composed of silicalite- 1 nanosheets of $2 \mathrm{~nm}$ of thickness aggregated $(0.5 \mu \mathrm{m})$

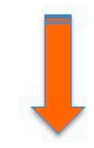

B130-2;B130-3

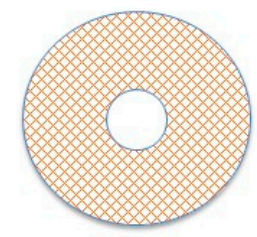

Hollow spheres composed of aggregated $(0.6-1.2 \mu \mathrm{m})$ nanosheets $(2 \mathrm{~nm})$

Figure 7. Schematic representation of the pseudomorphic transformation of silica amorphous beads into silicalite- 1 beads or hollow spheres composed of silicalite- 1 nanosheets samples $\left(\mathrm{B}-\mathrm{T}\left({ }^{\circ} \mathrm{C}\right)\right.$ - $\mathrm{t}($ days $\left.)\right)$ as a function of the hydrothermal temperature $\left(\mathrm{T}\right.$ in $\left.{ }^{\circ} \mathrm{C}\right)$ and duration ( $\mathrm{t}$ in days).

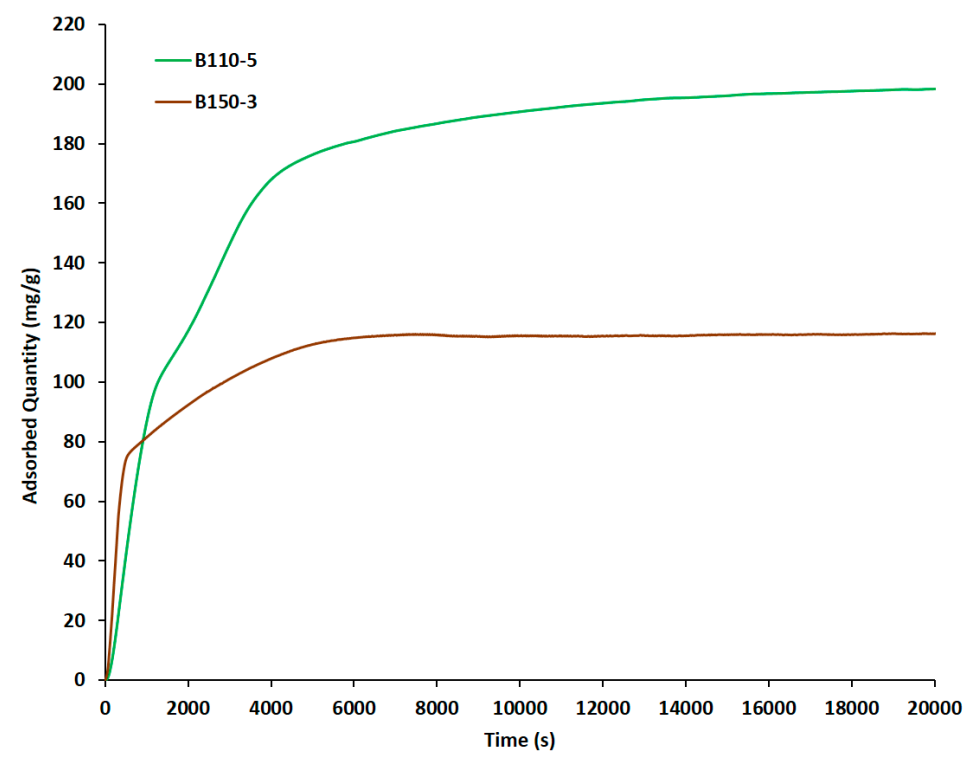

Figure 8. Adsorption kinetic of n-hexane at $25^{\circ} \mathrm{C}$ and $\mathrm{p} / \mathrm{p}^{\circ}=1$ with silicalite- 1 beads synthesized at $110^{\circ} \mathrm{C}$ for 5 days (B110-5) and hollow spheres synthesized at $150{ }^{\circ} \mathrm{C}$ for 3 days (B150-3). 


\section{Materials and Methods}

\subsection{Preparation of Silicalite-1 Beads}

\subsubsection{Structure Directing Agent}

The di-quaternary ammonium-type surfactant used for the transformation of amorphous silica spheres into MFI-type nanosheets spheres, $\left(\left[\mathrm{C}_{22} \mathrm{H}_{45}-\mathrm{N}^{+}\left(\mathrm{CH}_{3}\right)_{2}-\mathrm{C}_{6} \mathrm{H}_{12}-\mathrm{N}^{+}\left(\mathrm{CH}_{3}\right)_{2}-\mathrm{C}_{6} \mathrm{H}_{13}\right] \mathrm{Br}_{2}\right)$ named $\left(\mathrm{C}_{22-6-6}\right)$ was obtained in two steps following the procedure reported by Choi et al. [40] The surfactant was composed of a long-chain alkyl group $\left(C_{22}\right)$ and two quaternary ammonium groups spaced by a $\mathrm{C}_{6}$ alkyl linkage.

\subsubsection{Pseudomorphic Synthesis of Silicalite-1 Nanosheet Spheres}

Pseudomorphic transformation were performed using as silica source, amorphous porous silica spheres SilicaSphere ${ }^{\mathrm{TM}}$ delivered by Silicycle ${ }^{\circledR}$. These mesoporous silica beads have sizes of $20 \mu \mathrm{m}$ and mean pore diameters of 6 or $8 \mathrm{~nm}$ (data given by the supplier). $0.4 \mathrm{~g}$ of Sodium hydroxide (Carlo Erba, Val de Reuil, France, 99\%) is dissolved in $12 \mathrm{~mL}$ deionized water in a beaker. Then $1.35 \mathrm{~g}$ of $\mathrm{C}_{22-6-6}$ and $0.31 \mathrm{~g}$ of sulfuric acid (Sigma-Aldrich, Saint Louis, MO, USA, 96\%) were then added under stirring. After homogenization, the solution is transferred in a $45 \mathrm{~mL}$ Teflon ${ }^{\circledR}$-lined stainless steel autoclave containing $1 \mathrm{~g}$ of amorphous silica spheres with $20 \mu \mathrm{m}$ size to set the molar composition of the gel to: $1 \mathrm{SiO}_{2}: 0.3 \mathrm{Na}_{2} \mathrm{O}: 0.18 \mathrm{H}_{2} \mathrm{SO}_{4}: 0.1 \mathrm{C}_{22-6-6}: 40 \mathrm{H}_{2} \mathrm{O}$. The autoclave was placed in an oven for various temperature and heating time in static mode.

After synthesis the product was recovered by filtration, washed with water and dried overnight at $80{ }^{\circ} \mathrm{C}$. The $\mathrm{C}_{22-6-6}$ surfactant was removed by calcination in a muffle furnace at $550{ }^{\circ} \mathrm{C}$ at a rate of $1{ }^{\circ} \mathrm{C} / \mathrm{min}$ for $8 \mathrm{~h}$. The resulting zeolite beads will be named (B-T $\left({ }^{\circ} \mathrm{C}\right)-\mathrm{t}($ days $\left.)\right)$, where " $\mathrm{T}^{\prime \prime}$ stands for the hydrothermal treatment temperature and " $\mathrm{t}$ " stands for the duration of the hydrothermal treatment in days.

\subsection{Characterization of Zeosils}

The purity and the crystallinity of the calcined silicalite- 1 microspheres were checked by XRD analysis. X-ray diffraction patterns of the different materials introduced in a glass capillaries were recorded using a STOE STADI-P diffractometer (STOE $\delta$ Cie GmbH, Darmstadt, Germany) operating with $\mathrm{Cu} \mathrm{K} \alpha_{1}$ radiation $(\lambda=0.15406 \mathrm{~nm})$ in the range $3<2 \theta<40^{\circ}$.

The size and the morphology of the calcined zeosil spheres were determined by scanning electron microscopy (SEM) (an average was obtained by measuring 100 particles for each sample) using a Philips XL 30 FEG (Field Emission Gun) microscope (Verdun, France). The size of the silicalite-1 nanosheet crystals composing the spheres (an average was obtained by measuring the thickness of 100 nanosheets for each sample) was determined using a transmission electron microscopy (TEM) JEOL (Val de Reuil, France) model ARM-200F, under an acceleration voltage of $200 \mathrm{kV}$, with a point-to-point resolution of $80 \mathrm{pm}$. In order to detect the hollow presence or not in the inner part and the homogeneity of the beads with SEM, samples were embedded in cold mounting epoxy type resin (Struers, Epofix, Champigny sur Marne, France). Embedded beads were then grinded with various SiC grinding papers and finally polished with diamond polishing suspension (particle size $1 \mu \mathrm{m}$ ) until obtaining a soft surface.

Nitrogen adsorption/desorption isotherms at $-196{ }^{\circ} \mathrm{C}$ were measured using a Micromeritics ASAP 2420 apparatus (Micromeritics, Merignac, France). Prior to the adsorption measurements, the calcined samples were outgassed for $1 \mathrm{~h}$ at $90^{\circ} \mathrm{C}$ and then at $300^{\circ} \mathrm{C}$ overnight under vacuum. The microporous volumes were determined from t-plot method by applying when needed a correction according to Galarneau et al. [37]. Mesoporous volume was found by subtracting the microporous volume from the total porous volume. The pore diameter distributions were obtained from the adsorption branch by applying DFT method that is reliable over the complete range of micro- and mesopores [38,41]. 


\subsection{Dynamic n-Hexane Adsorption Measurements}

Dynamic adsorption measurements were performed under VOC atmosphere (n-hexane) at $25^{\circ} \mathrm{C}$ and controlled value of relative pressure $\mathrm{p} / \mathrm{p}^{\circ}=1\left(\mathrm{p}\right.$ is the vapor pressure and $\mathrm{p}_{0}$ is the saturation vapor pressure of $\mathrm{n}$-hexane at $25^{\circ} \mathrm{C}\left(\mathrm{p}^{\circ}=202 \mathrm{hPa}\right)$ using a thermogravimetric TG92 instrument (Setaram, Caluire et Cuire, France) $[1,2,36]$. The experiments were done under $\mathrm{N}_{2}$ flow. The gas flow rate was stable $(114 \mathrm{~mL} / \mathrm{min})$. The experiment begun with an activation phase: the zeolites were heated up to $350^{\circ} \mathrm{C}$ under dried nitrogen for $2 \mathrm{~h}$, at atmospheric pressure to remove all adsorbate traces. Then, the sample was cooled to $25^{\circ} \mathrm{C}$, and the organic compound was introduced to the system. The adsorbed amount was then measured every $20 \mathrm{~s}$.

\section{Conclusions}

This work highlights the pseudomorphic transformation of silica amorphous beads $(20 \mu \mathrm{m})$ into zeolite beads or hollow spheres of the same size constituted of an agglomeration of particles $(0.5-3 \mu \mathrm{m})$ composed of pure silica MFI-type nanosheets, by using di-quaternary ammonium-type surfactant. This strategy seems transposable to several other pure silica zeolite structures. It provides a simple and efficient new synthesis way for obtaining zeolitic beads and hollow spheres of controlled size. The crystallization seems to begin at the outer surface of the beads allowing at higher treatment temperature the acceleration of the dissolution kinetic of the inner amorphous part of the beads to form hollow spheres. Both plain beads and hollow spheres of silicalite- 1 showed to be promising for molecular decontamination in continuous flow by adsorbing n-hexane in high amount.

This strategy of pseudomorphic transformation of silica amorphous beads into zeolite beads or hollow spheres seems transposable to several other zeolite structures. It provides a simple and efficient one shot synthesis way for obtaining zeolitic beads or hollow spheres of controlled size without the use of binders for industrial applications.

Supplementary Materials: The following are available online at http://www.mdpi.com/1420-3049/25/11/2563/s1, Figure S1: t-plot for $\mathrm{N}_{2}$ adsorbed at $-196^{\circ} \mathrm{C}$ in B110-2, B110-3, B110-5, B130-2, B130-3, B150-1, B150-2, B150-3, B150-4, and B150-5.

Author Contributions: Conceptualization, T.J.D. and B.L.; methodology, K.M., T.J.D., J.T., and B.L.; validation, L.J.; investigation, K.M.; data curation, K.M., T.J.D., A.G., and B.L.; writing-original draft preparation, T.J.D.; writing-review and editing, T.J.D., B.L., and A.G.; supervision, T.J.D., J.T., T.H., and B.L.; project administration, T.J.D., and B.L.; funding acquisition, T.J.D. All authors have read and agreed to the published version of the manuscript.

Funding: This research was funded by Institut Universitaire de France (IUF), France.

Acknowledgments: The XRD: adsorption and Electronic microscopies platforms of IS2M are acknowledged. Laure Michelin, Habiba Nouali, Ludovic Josien, and Loï Vidal are warmly thanked for their help in XRD, N 2 adsorption-desorption, SEM and TEM acquisition data, respectively. The authors would like to thanks also the "Institut Universitaire de France" (IUF) for financial support.

Conflicts of Interest: The authors declare no conflict of interest.

\section{References}

1. Cosseron, A.-F.; Daou, T.J.; Tzanis, L.; Nouali, H.; Deroche, I.; Coasne, B.; Tchamber, V. Adsorption of volatile organic compounds in pure silica CHA, *BEA, MFI and STT-type zeolites. Micro. Meso. Mater. 2013, 173, 147-154. [CrossRef]

2. Kabalan, I.; Rioland, G.; Nouali, H.; Lebeau, B.; Rigolet, S.; Fadlallah, M.-B.; Toufaily, J.; Hamiyeh, T.; Daou, T.J. Synthesis of purely silica MFI-type nanosheets for molecular decontamination. RSC Adv. 2014, 4, 37353-37358. [CrossRef]

3. Kabalan, I.; Khay, I.; Nouali, H.; Ryzhikov, A.; Lebeau, B.; Albrecht, S.; Rigolet, S.; Fadlallah, M.-B.; Toufaily, J.; Hamiyeh, T.; et al. Influence of the particle sizes on the energetic performances of MFI-type zeolites. J. Phys. Chem. C 2015, 119, 18074-18083. [CrossRef]

4. Eroshenko, V.; Regis, R.C.; Soulard, M.; Patarin, J. Energetics: A new feld of applications for hydrophobic zeolites. J. Am. Chem. Soc. 2001, 123, 8129-8130. [CrossRef] 
5. Tzanis, L.; Nouali, H.; Daou, T.J.; Soulard, M.; Patarin, J. Influence of the aqueous medium on the energetic performances of Silicalite-1. Mater. Letter. 2014, 115, 229-232. [CrossRef]

6. Deroche, I.; Daou, T.J.; Picard, C.; Coasne, B. Reminiscent capillarity in subnanopores. Nature Com. $2019,10$. [CrossRef]

7. Pascual, P.; Ungerer, P.; Tavitian, P.; Pernot, P.; Boutin, A. Development of a transferable guest-host force field for adsorption of hydrocarbons in zeolites. Phys. Chem. Chem. Phys. 2003, 5, 3684-3693. [CrossRef]

8. Rioland, G.; Daou, T.J.; Faye, D.; Patarin, J. A new generation of MFI-type zeolite pellets with very high mechanical performance for space decontamination. Micro. Meso. Mater. 2016, 221, 167-174. [CrossRef]

9. Bingre, R.; Louis, B.; Nguyen, P. An Overview on Zeolite Shaping Technology and Solutions to Overcome Diffusion Limitations. Catalysts. 2018, 8, 163. [CrossRef]

10. Lauridant, N.; Daou, T.J.; Arnold, G.; Soulard, M.; Nouali, H.; Patarin, J.; Faye, D. Key steps influencing the formation of ZSM-5 films on aluminum substrates. Micro. Meso. Mater. 2012, 152, 1-8. [CrossRef]

11. Schumann, K.; Unger, B.; Brandt, A.; Scheffler, F. Investigation on the pore structure of binderless zeolite $13 \times$ shapes. Micro. Meso. Mater. 2012, 154, 119-123. [CrossRef]

12. Rioland, G.; Bullot, L.; Daou, T.J.; Simon-Masseron, A.; Chaplais, G.; Faye, D.; Fiani, E.; Patarin, J. Elaboration of FAU-type zeolite beads with good mechanical performances for molecular decontamination. RSC Adv. 2016, 6, 2470-2478. [CrossRef]

13. Lauridant, N.; Daou, T.J.; Arnold, G.; Patarin, J.; Faye, D. MFI/*BEA hybrid coating on aluminum alloys. Micro. Meso. Mater. 2013, 166, 79-85. [CrossRef]

14. Daou, T.J.; Lauridant, N.; Josien, L.; Arnold, G.; Faye, D.; Patarin, J. Synthesis of MFI/EMT zeolite bi-layer films for molecular decontamination. Chem. Eng. J. 2013, 234, 66-73. [CrossRef]

15. Said, A.; Lionel, L.; Nouali, H.; Michelin, L.; Halawani, J.; Toufaily, J.; Hamiyeh, T.; Dutournié, P.; Daou, T.J. Synthesis of mono- and bi-layer MFI zeolite films on macroporous alumina tubular supports: Application to nanofiltration. J. Cryst. Growth. 2015, 428, 71-79. [CrossRef]

16. Fawaz, E.G.; Salam, D.A.; Nouali, H.; Deroche, I.; Rigolet, S.; Lebeau, B.; Daou, T.J. Synthesis of binderless ZK-4 zeolite microspheres at high temperature. Molecules 2018, 23, 2647. [CrossRef]

17. Li, C.; Wang, Y.; Shi, B.; Ren, J.; Liu, X.; Wang, Y.; Gua, Y.; Gua, Y.; Lu, G. Synthesis of hierarchical MFI zeolite microspheres with stacking nanocrystals. Micro. Meso. Mater. 2009, 117, 104-110. [CrossRef]

18. Manko, M.; Vittenet, J.; Rodriguez, J.; Cot, D.; Mendret, J.; Brosillon, S.; Makowskia, W.; Galarneau, A. Synthesis of binderless zeolite aggregates (SOD, LTA, FAU) beads of $10,70 \mu \mathrm{m}$ and $1 \mathrm{~mm}$ by direct pseudomorphic transformation. Micro. Meso. Mater. 2013, 176, 145-154. [CrossRef]

19. Yue, N.; Xue, M.; Qiu, S. Fabrication of hollow zeolite spheres using oil/water emulsions as templates. Inorg. Chem. Commun. 2011, 14, 1233-1236. [CrossRef]

20. Chen, H.; Liu, X.; Ma, X. Confined synthesis of silicalite-1 hollow spheres with a lamellar shell. Scripta Materialia 2015, 95, 31-34. [CrossRef]

21. Pashkova, V.; Tokarova, V.; Brabec, L.; Dedecek, J. Self-templating synthesis of hollow spheres of zeolite ZSM-5 from spray-dried aluminosilicate precursor. Micro. Meso. Mater. 2016, 228, 59-63. [CrossRef]

22. Yan, B.; Zeng, C.; Yu, L.; Wang, C.; Zhang, L. Preparation of hollow zeolite NaA/chitosan composite microspheres via in situ hydrolysis-gelation-hydrothermal synthesis of TEOS. Micro. Meso. Mater. 2018, 257, 262-271. [CrossRef]

23. Wang, Z.; Guan, J.; Wu, S.; Xu, C.; Ma, Y.; Lei, J.; Kan, Q. Preparation of uniform Silicalite-1 microspheres with large secondary pore architecture using monodisperse porous polystyrene particles as template. Mater. Lett. 2010, 64, 1325-1327. [CrossRef]

24. Yin, C.; Tian, D.; Xu, M.; Wei, Y.; Bao, X.; Chen, Y.; Wang, F. One-step synthesis of hierarchical mesoporous zeolite beta microspheres from assembly of nanocrystals. J. Colloid Interface Sci. 2013, 397, 108-113. [CrossRef]

25. Tao, H.; Yang, H.; Zhang, Y.; Ren, J.; Liu, X.; Wang, Y.; Lu, G. Space-confined synthesis of nanorod oriented-assembled hierarchical MFI zeolite microspheres. J. Mater. Chem. A 2013, 1, 13821-13827. [CrossRef]

26. Wang, Y.; Ma, J.; Ren, F.; Du, J.; Li, R. Hierarchical architectures of ZSM-5 nanocrystalline aggregates with particular catalysis for lager molecule reaction. Micro. Meso. Mater. 2017, 240, 22-30. [CrossRef]

27. Tosheva, L.; Valtchev, V.; Sterte, J. Silicalite-1 containing microspheres prepared using shape-directing macro-templates. Micro. Meso. Mater. 2000, 35-36, 621-629. [CrossRef]

28. Tosheva, L.; Mihailova, B.; Valtchev, V.; Sterte, J. Zeolite beta spheres. Micro. Meso. Mater. 2001, 48, 31-37. [CrossRef] 
29. Yin, C.; Wei, Y.; Wang, F.; Chen, Y. Introduction of mesopority in zeolite ZSM-5 using resin as templates. Mater. Lett. 2013, 98, 194-196. [CrossRef]

30. Galarneau, A.; Sachse, A.; Said, B.; Pelisson, C.-H.; Boscaro, P.; Brun, N.; Courtheoux, L.; Olivi-Tran, N.; Coasne, B.; Fajula, F. Hierarchical porous silica monoliths: A novel class of microreactors for process intensification in catalysis and adsorption. C. R. Chimie 2016, 19, 231-247. [CrossRef]

31. Didi, Y.; Said, B.; Micolle, M.; Cacciaguerra, T.; Cot, D.; Geneste, A.; Fajula, F.; Galarneau, A. Nanocrystals FAU-X monoliths as highly efficient microreactors for cesium capture in continuous flow. Microporous Mesoporous Mater. 2019, 285, 185-194. [CrossRef]

32. Said, B.; Grandjean, A.; Barre, Y.; Tancret, F.; Fajula, F.; Galarneau, A. LTA zeolite monoliths with hierarchical trimodal porosity as highly efficient microreactors for strontium capture in continuous flow. Microporous Mesoporous Mater. 2016, 232, 39-52. [CrossRef]

33. Moukahhal, K.; Daou, T.J.; Josien, L.; Nouali, H.; Toufaily, J.; Hamieh, T.; Galarneau, A.; Lebeau, B. Hierarchical ZSM-5 beads composed of zeolite nanosheets obtained by pseudomorphic transformation. Microporous Mesoporous Mater. 2019, 288. [CrossRef]

34. Database of Zeolite Structures, version 2017, Framework chemical composition included for all materials in the database; Structure Commission of the International Zeolite Association (IZA-SC): Switzerland. 2017. Available online: http://www.iza-structure.org/databases/ (accessed on 20 March 2020).

35. El Hanache, L.; Sundermann, L.; Lebeau, B.; Toufaily, J.; Hamieh, T.; Daou, T.J. Surfactant-modified MFI-type nanozeolites: Super-adsorbents for nitrate removal from contaminated water. Microporous Mesoporous Mater. 2009, 117, 104-110. [CrossRef]

36. Kabalan, I.; Lebeau, B.; Nouali, H.; Toufaily, J.; Hamiyeh, T.; Daou, T.J. New Generation of Zeolite Materials for Environmental Applications. J. Phys. Chem. C. 2016, 120, 2688-2697. [CrossRef]

37. Galarneau, A.; Mehlhorn, D.; Guenneau, F.; Coasne, B.; Villemot, F.; Minoux, D.; Aquino, C.; Dath, J.P. Specific Surface Area Determination for Microporous/Mesoporous Materials: The Case of Mesoporous FAU-Y Zeolites. Langmuir. 2018, 34, 14134-14142. [CrossRef]

38. Thommes, M.; Cychosz, K.A. Physical adsorption characterization of nanoporous materials: Progress and challenges. Adsorption 2014, 20, 233-250. [CrossRef]

39. Vlugt, T.J.H.; Krishna, R.; Smit, B. Molecular Simulations of Adsorption Isotherms for Linear and Branched Alkanes and Their Mixtures in Silicalite. J. Phys. Chem. B. 1999, 103, 1102-1118. [CrossRef]

40. Choi, M.; Na, K.; Kim, J.; Sakamoto, Y.; Terasaki, O.; Ryoo, R. Stable single-unit-cell nanosheets of zeolite MFI as active and long-lived catalysts. Nature. 2009, 461, 246-249. [CrossRef]

41. Landers, J.; Gor, G.Y.; Neimark, A.V. Density functional theory methods for characterization of porous materials. Colloids Surf. A Physicochem. Eng. Asp. 2013, 437, 3-32. [CrossRef]

Sample Availability: Samples of the compounds are available from the authors.

(C) 2020 by the authors. Licensee MDPI, Basel, Switzerland. This article is an open access article distributed under the terms and conditions of the Creative Commons Attribution (CC BY) license (http://creativecommons.org/licenses/by/4.0/). 